Skrypnyk M. I.

Doctor of Economics, Associate Professor, Head of Accounting and Auditing, Kyiv National University of Technology and Design, (Kyiv),

Ukraine; e-mail:margarita1111@ukr.net

Vyhivska I. M.

PhD, Associate Professor,

Zhytomyr State Technological University, assistant professor of accounting and auditing,(Zhitomir),

Ukraine; e-mail:vygovskaya_irina@mail.ru

Grabczuk I. L.

PhD, Associate Professor, assistant professor of accounting and auditing, Zhytomyr State Technological University, (Zhitomir),

Ukraine; e-mail:til83@mail.ru

Hryhorevska 0.0 .

PhD, Associate Professor, assistant professor of accounting and auditing, Kyiv National University of Technology and Design, (Kyiv),

Ukraine; e-mail:lenazelenina@ukr.net

\title{
PENSION REFORM OF UKRAINE AS A KEY TO SOCIAL SECURITY: THREATS AND PROSPECTS
}

\begin{abstract}
The need to improve standards of living requires a review of the components of social policy. The article is based on an analysis of the provisions of existing pension systems around the world, studying the experience of pension reforms they confirmed the need for pension reform in Ukraine. Preconditions pension reform (complicated demographic situation, low pension, opacity systems, social injustice) in Ukraine, revealed that issues of implementation. Considered reservations about introducing a funded system of compulsory state pension insurance, which is decorated in a matrix of threats and opportunities, and conducted SWOT-analysis of pension reform to ensure social security. The list of indicators of social security, the calculation of which the conclusions on the effectiveness of the implementation of the pension reform.
\end{abstract}

Keywords: social responsibility, pension reform, social security, storage system, pensions

JEL Classification: G23, H55, J32

Formulas: 0; fig.: 1, tabl.: 1, bibl.: 10

Скрипник М. I.

д.е.н., доцент, завідувач кафедри обліку і аудиту, Киівський національний університет технологій та дизайну, (м. Київ),

Україна; e-mail:margarita1111@ukr.net

Вигівська I. M.

к.е.н., доцент, доиент кафедри обліку і аудиту, Житомирський державний технологічний університет, (м. Житомир), Україна; e-mail:vygovskaya_irina@mail.ru

Грабчук I. Л.

к.е.н., доиент, доиент кафедри обліку і аудиту, Житомирський державний технологічний університет, (м. Житомир),

Україна; e-mail:til83@mail.ru

Григоревська О.O.

к.е.н., доцент, доиент кафедри обліку і аудиту, Київський національний університет технологій та дизайну, (м. Київ), Україна; e-mail:lenazelenina@ukr.net

\section{ПЕНСІЙНА РЕФОРМА УКРАЇНИ ЯК ЗАПОРУКА СОЦІАЛЬНОЇ БЕЗПЕКИ: ЗАГРОЗИ ТА ПЕРСПЕКТИВИ}


Анотація. Необхідність підвищення стандартів життя населення вимагає перегляду складових соціальної політики держави. В статті на основі аналізу положень діючих пенсійних систем різних країн світу, вивчення досвіду проведення в них пенсійних реформ підтверджено необхідність проведення пенсійної реформи в Україні. Визначено передумови пенсійної реформи (складна демографічна ситуація, низький розмір пенсії, непрозорість системи, соціальна несправедливість) в Україні, що дозволило встановити проблемні питання іiї впровадження. Розглянуто застереження щодо запровадження накопичувальної системи загальнообов'язкового державного пенсійного страхування, які оформлено в матрицю загроз та можливостей, та проведено SWOT-аналіз впровадження пенсійної реформи для забезпечення соціальної безпеки. Визначено перелік індикаторів соціальної безпеки, за розрахунком яких здійснюється висновки щодо ефективності реалізації пенсійної реформи.

Ключові слова: соціальна відповідальність, пенсійна реформа, соціальна безпека, накопичувальна система, пенсійне забезпечення

Формул: 0; рис.: 1, табл.: 1, бібл.: 10

Скрипник М. И.

д.э.н., доцент, заведующий кафедрой учета и аудита, Киевский национальный университет технологий и дизайна, (2.Киев),

Украина; e-mail:margarita1111@ukr.net

Выговская И. Н.

к.э.н., доиент, доиент кафедры учета и аудита, Житомирский государственный технологический университет, (2. Житомир),

Украина; e-mail: vygovskaya_irina@mail.ru

Грабчук И. Л.

к.э.н., доиент, доцент кафедры учета и аудита, Житомирский государственный технологический университет,

(2 Житомир), Украина, e-mail: til83@mail.ru

Григоревская $\mathrm{E}$. $\boldsymbol{A}$.

к.э.н., дочент, дочент кафедры учета и аудита, Киевский национальный университет технологий и дизайна, (2. Киев), Украина; , e-mail:lenazelenina@ukr.net

\section{ПЕНСИОННАЯ РЕФОРМА УКРАИНЫ КАК ЗАЛОГ СОЦИАЛЬНОЙ БЕЗОПАСНОСТИ: УГРОЗЫ И ПЕРСПЕКТИВЫ}

Аннотация. Необходимость повышения стандартов жизни населения требует пересмотра составляющих социальной политики государства. В статье на основе анализа положений действующих пенсионных систем разных стран мира, изучения опыта проведения в них пенсионных реформ подтверждена необходимость проведения пенсионной реформы в Украине. Определены предпосылки пенсионной реформы (сложная демографическая ситуация, низкий размер пенсии, непрозрачность системы, социальная несправедливость) в Украине, что позволило установить проблемные вопросы ее применения. Рассмотрены предостережения о введении накопительной системы общеобязательного государственного пенсионного страхования, оформленые в матрицу угроз и возможностей, и проведен SWOT-анализ внедрения пенсионной реформы для обеспечения социальной безопасности. Определен перечень индикаторов социальной безопасности, по расчету которых осуществляются выводы об эффективности реализации пенсионной реформы.

Ключевые слова: социальная ответственность, пенсионная реформа, социальная безопасность, накопительная система, пенсионное обеспечение.

Формул: 0; рис.: 1, табл.: 1, библ.: 10 
Introduction. The current crisis in the global economy exacerbates the problem of an aging population. Almost all global corporations dismiss their employees who have reached retirement age on mass scale Herewith the new employees, which are the potential taxpayers, are not hired. That means the whole public pension provision costs are being disposed on the government whose budget is not always able to withstand, under extensive, mode of development of the economy, not innovative.

The Pension Fund of Ukraine (hereinafter - PFU) costs for 2017 total UAH 283,68 bln., whereas its own revenues amount UAH $141,8 \mathrm{bln}$ The remaining amount (142,00 bln.), accounting for $21 \%$ of GDP is expected to be subsidized from the government budget. The experts predicted that this figure would double by 2050 .

We should remark that Ukraine is considered a country with a significant pressure of PFU on GDP. Comparing similar expenditures undertaken in Belarus, Poland, Germany, Portugal, you can note that the pension costs account for $10 \%$ of GDP. Thus, the share of spending in Ukraine today is among the highest in the world.

There are several reasons of the situation The first is a small amount of GDP. Today it is about USD $347885 \mathrm{mln}$. (i. e. USD $8162 \mathrm{mln}$ per capita) [1]. For comparison, our closest neighbors, Poland - USD 1050948 mln.. (i. e. USD 27.349 bln. per capita), Romania 441032000000 dollars. (i. e. USD 22.319 bln. per capita), Czech Republic - 350861000000 dollars (i.e. USD 33.186 bln. per capita).

Another reason can be a shadow angle of the economy. According to estimates of the Ministry of Economic Development and Trade of Ukraine in January-September 2016 the level of shadow economy amounted to $35 \%$ of the official GDP [2], therefore, it is obvious that payments to PFU from $35 \%$ income revenues were not made. It should be emphasized that this figure went 5 percentage points down from the index of the corresponding period in 2015. The situation made the government reduce the share of solidary pension system and increase the share of accumulative one that will help reduce the financial pressure on public sector of social benefits, and Ukraine will enable citizens to active participation in social security provision.

Research and Analysis of aim. The expediency of pension reform was studied by $O$. Koval, B. Poplyko, M. Vorobiov, Yu. Havrylchenko, O. Nasibova,, Schwartz A.M. (Schwarz A.M.) and others. Without belittling the contribution of scholars we can accentuate that the effective ways to develop the idea of a qualitatively new cooperation between the state, society and business organizations to improve the overall level of social welfare have not been developed yet.

The aim of the article is to study the issues of pension reform implementation, define its place in the system of social security and give recommendations for its implementation

The methods used in the study are observation, comparison, analysis, synthesis, induction, deduction, generalization, economic and statistical method and the method of analogies.

Research results. Integral criterion of complementarity of economic efficiency and social justice at the state level is the level of social security, the development of the state to be able to provide an adequate life standards for the population, regardless of age, gender, income level, encourage the development of human capital as an essential component of economic capacity of the country.

The integral index of social security in 2015 in Ukraine was 52.5\%, which is an inadequate characteristic. Instability of the situation in the social sphere leads to a decrease in social stability and justice in the country. [3]

The above cause the need to determine the place of local social policy as a part of economic policy (based on methodological recommendations for calculating the economic security of Ukraine, approved by the Ministry of Economic Development and Trade of Ukraine of 29 October, 2013, Act № 1277 [4]), identify its elements, which would become the theoretical foundation for its effective implementation, and provide operational management decisions to minimize risks (Fig. 1).

Pension reform being one of the main elements of the subject of the national social policy and one of the most problematic issues in the current environment requires the closest attention. 


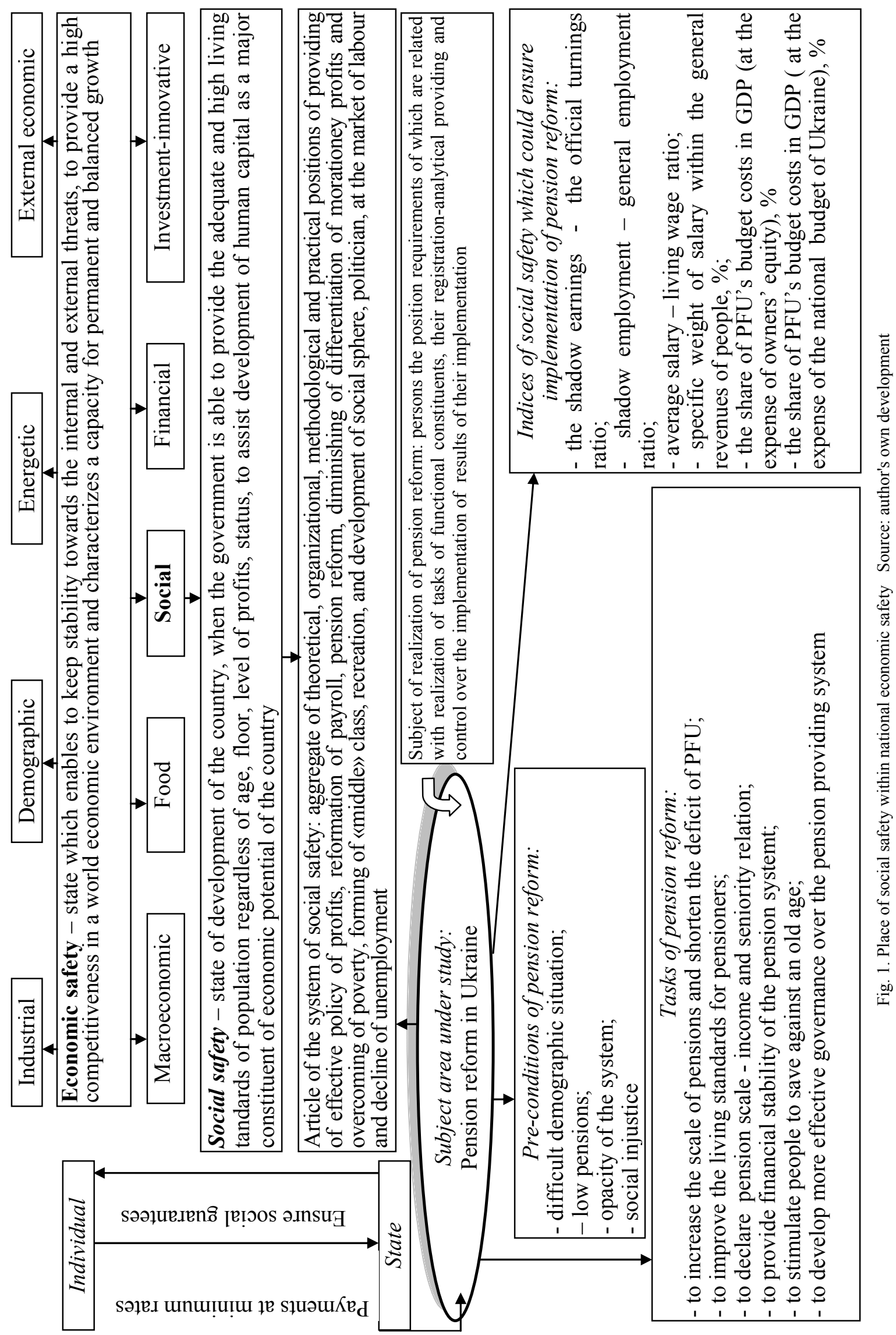


After all, the pension system in each country should be aimed at reducing poverty among the elderly, as well as smoothing the standard of living for the working population and pensioners as old age or disability reduces the ability to make [5]. That is why we have outlined issues to keep in mind when grounding provisions of the pension reform. The demographic situation. Ukraine has a PAYG pension system. That is, the working population paying Single Contribution ensure those receiving pensions. The existing distribution system balancing between the needs of disabled people and the interests of workers. However, with the deteriorating demographic situation where the proportion of the working population is falling every year, while the number and proportion of seniors increases, the budget is more difficult to "pull" on a pension payment.

This situation is observed in most countries. As an example, in Belarus sufficiently high proportion of working age population of 5 million 623 thousand. People (2014). However, due to the reduction of child population (in 1970 per 1,000 working age had 586 children under 16, 356 in 2000, and in early 2011, 261 children) and the low birth rate (rate of 1.69 in 2014 ) experts predict an increase in pension burden on workers. [6] In Bulgaria also has a tendency to reduce the number of working population. In particular, according to statistics every year it decreased by 54,000 persons; on 1 January 2017 was about $60 \%$ of the population [7].

Forecasts for the Ukraine made by UN experts [8] proved to be quite pessimistic: the end of 2050 Ukraine's population could shrink by 9 million people and reach 33.6 million. Of them $-15 \%-$ people younger than 15 years, and $16 \%$ will reach people older 65 . Furthermore, the explanatory note it is also that the population decline will be parallel to its aging, leading to the fact that the number of pensioners will exceed the working-age population, and today accounts for one pensioner one person of working age.

Low pension. An important issue is the problem low pensions. In Ukraine, the average pension size is 2000 USD., Which is 72 dollars. For comparison, the average Pole receives 6.5 times higher than the Ukrainian retired. A Russian - three times. And the size of the average pension in December 2016 in Belarus amounted to $\$ 156$. Over $1,228,000$ or $56.4 \%$ of Bulgarian pensioners as of the beginning of 2015 receive a pension, including all allowances it does not exceed the threshold of poverty in the country at 285.92 leva (about 155.5 dollars.). The minimum pension in Bulgaria is 155 leva (84.3 dollars). And as reported in studies of European Statistics Service "Eurostat", more than 45\% of pensioners in Bulgaria continue to operate as pension received is not enough to ensure a normal life.

The average pension amounts to 150.3 euros. The average pension in Ukraine is only $33 \%$ of the Opacity system and social injustice. Ordinary man is difficult to independently calculate their pension, and Ukraine does not practice in advance to inform citizen about pension. Because of the opacity of the current distribution system in Ukraine is not much confidence in the population. In this regard, Ukraine has widespread wages "in envelopes".

Lack of pension depending on seniority and setting unreasonably high pensions for certain categories of citizens exacerbate the problem of social injustice in the country. In addition, as noted by A. Nasibova, the current "... the pension system overloaded with a number of benefits and payments, which by their nature are not to be inherent and should be the individual elements of social insurance and social security» [9, p. 169].average salary (5034 USD).

The above highlights that the current pension system is outdated and requires comply with the actual economic relations. Despite the controversial nature, yet government officials, researchers and scientists tend to introduction in Ukraine three-level pension system, which is inherent in most foreign countries. Characterize the example of a system in Bulgaria. In 2000, Bulgaria was carried out pension reform and introduced a three-tier model.

I level - social insurance based on the principle of solidarity and managed by the National Institute of Insurance. With contributions from workers are paid pensions of today's pensioners. This provision is mandatory and covers virtually all working population.

II level - compulsory pension insurance is based on equity. Resources for each insured person accumulates in his individual account under which the pension is calculated. Additional mandatory pension insurance by private pension insurance companies managed their universal and professional pension funds In other countries the figure is much higher. For example, in the UK the ratio between pensions and salaries up to $90 \%$, Poland $58 \%, 42 \%$ in Belarus, in Russia $38 \%$

III-level - a contract for voluntary pension insurance and is based on equity. Thus the resources of each insured person accumulates in his individual account under which the pension is calculated. 
Voluntary pension funds managed by the same pension companies. Participation in these funds, however, is voluntary. [10]

If the transfer of experience of foreign countries in Ukraine, it should be noted that experts from international financial institutions are advised to refrain from the introduction of a funded pension system, in particular about this in a letter to the IMF.

We offer consider some reservations about the introduction of a funded system of compulsory state pension insurance and place them in a matrix of threats and opportunities, diverting it from the plane of the enterprise and national level (Table. 1).

Table 1

Matrix SWOT-analysis of pension reform implementation for social security provision

\begin{tabular}{|c|c|c|}
\hline \multirow{6}{*}{$\begin{array}{l}\text { SWOT-analysis } \\
\text { ingredients }\end{array}$} & Opportunity & Threats \\
\hline & $\begin{array}{l}\text { Increasing the pensions and reduction of } \\
\text { PFCs deficit }\end{array}$ & \multirow{2}{*}{$\begin{array}{l}\text { In economic crisis conditions the effect of } \\
\text { placing funds and use special accounts is } \\
\text { doubtful }\end{array}$} \\
\hline & $\begin{array}{l}\text { Ensuring the financial stability of the } \\
\text { pension system }\end{array}$ & \\
\hline & Raising living standards of pensioners & \multirow{2}{*}{$\begin{array}{l}\text { Failure state guarantee for citizens against } \\
\text { preservation of accumulated funds and } \\
\text { control over their placement and use }\end{array}$} \\
\hline & $\begin{array}{l}\text { The ability to determine the pension basis, } \\
\text { depending on the size of seniority and } \\
\text { wages }\end{array}$ & \\
\hline & $\begin{array}{l}\text { Development of more effective } \\
\text { governance of pensions }\end{array}$ & Shadowing of salaries \\
\hline Strength strategy & $\mathrm{SO}-$ strategy & ST-strategy \\
\hline $\begin{array}{l}\text { An effective reform } \\
\text { package }\end{array}$ & \multirow{3}{*}{$\begin{array}{l}\text { - calculating minimum pension not less } \\
\text { than the minimum subsistence level (not } \\
\text { budget figures but calculated value - at this } \\
\text { stage it is no more than } 2000 \text { UAH per } \\
\text { month); } \\
\text {-encouraging citizens to save money for } \\
\text { their retirement through the use of a simple } \\
\text { and transparent mechanism for calculating } \\
\text { pensions }\end{array}$} & \multirow{3}{*}{$\begin{array}{l}\text {-introduction of measures to minimize } \\
\text { the impact of the economic crisis on } \\
\text { accumulative pension funds (preference is } \\
\text { given to conservative investment pension } \\
\text { assets, enabling the postpone of the } \\
\text { members of the pension plan', withdrawal } \\
\text { even if they would reach the retirement } \\
\text { age); } \\
\text {-creation of guarantee funds or insurance } \\
\text { of savings to ensure their practical } \\
\text { implementation in fixing the average } \\
\text { wage of at least four living wages }\end{array}$} \\
\hline $\begin{array}{l}\text { Improving financial } \\
\text { literacy }\end{array}$ & & \\
\hline $\begin{array}{l}\text { Independence of } \\
\text { demographic } \\
\text { situation }\end{array}$ & & \\
\hline Weak sides & $\mathrm{WO}-$ strategy & WT - strategy \\
\hline $\begin{array}{l}\text { Redistribution of } \\
\text { deposits between } \\
\text { joint and storage } \\
\text { systems }\end{array}$ & \multirow{2}{*}{$\begin{array}{l}\text {-development of the stock market, which } \\
\text { performs its function of transforming } \\
\text { savings and assets; } \\
\text {-full guarantee pension payments from the } \\
\text { State Budget of Ukraine; } \\
\text { - provision of the banking, financial and } \\
\text { credit systems' stability; } \\
\text { - no restrictions on the use of their own } \\
\text { funds }\end{array}$} & \multirow{2}{*}{$\begin{array}{l}\text { - to ensure price stability (low inflation); } \\
\text { - implementation of effective state } \\
\text { control over the use of funds from } \\
\text { retirement accounts and non-use savings } \\
\text { accounts to perform extrinsic payments; } \\
\text { - balance the PFU budget for account of } \\
\text { additional resources of the national } \\
\text { budget of Ukraine }\end{array}$} \\
\hline Backset of PFU & & \\
\hline
\end{tabular}

Conducted SWOT-analysis revealed clearly structured information on pension reform in Ukraine, which in turn allows justify recommendations for the effective conduct of the said reforms.

Conclusions. Summarizing the results of the study on the implementation of pension reform to ensure the social security of the population of Ukraine (on the basis of SWOT-analysis), we define a number of problematic issues that require the most attention:- the economic crisis, high inflation accumulation system effectiveness is questionable, it is therefore appropriate implementation, provided that the country is in a post-crisis stage;

-introduction of jointly-funded system implies that some contributions were made to the solidarity system would aspire to accumulation. Thus, the deficit PFC increases, and at this stage no additional funds from the state budget of Ukraine can not do; 
- in the absence of an effective instrument to establish control over the placement and use of pension savings of citizens in the population formed distrustful attitude towards voluntary insurance. It is necessary to establish a fund to guarantee pension contributions, nomination harsh environment for companies to manage pension assets.

Thus, the development of the provisions of the pension reform should take into account the experience of foreign countries, in particular the conditions that have characterized the country's readiness to its implementation:

- providing minimize the negative effects of the introduction of a funded pension system on a PAYG pension system;

- economic growth, minimal inflation rooster, rising wages;

- development of appropriate information and consultation to ensure public on reforms to prevent their negative adjustment to the implemented measures.

\section{Література}

1. Таблица стран мира 2016 год (территория, население, ВВП) [Электронный ресурс]. - Режим доступа: http://seosait.com/state-world-2016-territory-population-gdp/

2. Тенденції тіньової економіки в Україні у січні-вересні 2016 року [Електронний ресурс]. - Режим доступу: http://www.me.gov.ua/Documents/Detail?lang=uk-UA\&id=5a655c5b-2e53-4562-9360-

c557c4dc9b83\&title=TendentsiiTinovoiEkonomikiVUkrainiUIPivrichchi2016-Roku.

3. Коваль, О. П. Соціальна безпека: сутність та вимір [Електронний ресурс] : наук. доп. / О. П. Коваль - К. : НІСД, 2016. - 34 c. - Режим доступу: http://www.niss.gov.ua/public/File/2016_nauk_anal_rozrob/social_bezpek.pdf.

4. Методичні рекомендації шодо розрахунку рівня економічної безпеки України від 29.10.2013 p. № 1277 [Електронний pecypc]. - Режим доступу: http://document.ua/pro-zatverdzhennja-metodichnihrekomendacii-shodo-rozrahunku-doc168080.html.

5. Schwarz, A. M. Pension System Reforms [Electronic resource] /A. M. Schwarz // Analyzing the Distributional Impact of Reforms. - 2006. - Vol. 2. - Available at: http://siteresources.worldbank.org/INTPSIA/Resources/4900231120845825946/PSIAVOLII printed.pdf.

6. Поплыко, В. Белорусская пенсионная система: немного арифметики [Электронный ресурс] / В. Поплыко // Памятная записка «Либерального клуба». - 2015. - № 5. - Режим доступа: http://liberalclub.biz/белорусская-пенсионная-система-немн/

7. Работна сила и коефициенти на икономическа активност - национално ниво; статистически райони [Электронный pecypc]. - Режим доступа: http://www.nsi.bg/bg/content/4007/paботна-сила-и-коефициенти-на-икономическа-активностнационално-ниво-статистически.

8. До 2050 року населення України скоротиться до 36 млн. осіб [Електронний ресурс]. - Режим доступу: http://dt.ua/UKRAINE/do-2050-roku-naselennya-ukrayini-skorotitsya-do-36-mln-osib-124859_html.

9. Насібова, О. В. Фінансове забезпечення державних пенсійних зобов'язань в умовах трансформаційної економіки [Текст] / О. В. Насібова // Науковий вісник Херсонського державного університету. Серія Економічні науки. - 2015. - Вип. 12, Ч. 2. -C. $166-170$.

10. Какво трябва да знам за допьлнителното пенсионно осигуряване [Электронный ресурс] / Комисия за финансов надзор. - София, 2009. -32 c. - Режим доступа: http://www.zastrahovatel.com/statia.php?mysid=3364\&t=6\&.

Стаття надійшла до редакиії 18.03.2017

(C) Скрипник M. I., Вигівська I. М., Грабчук І. Л., Григоревська О. О.

\section{References}

1. Tablitsa stran mira 2016 god (territoriia, naselenie, VVP). Available at: http://seosait.com/state-world-2016territory-population-gdp/

2. Tendentsii tinovoi ekonomiky $v$ Ukraini $u$ sichni-veresni 2016 roku. Available at: http://www.me.gov.ua/Documents/Detail?lang=uk-UA\&id=5a655c5b-2e53-4562-9360-

c557c4dc9b83\&title=TendentsiiTinovoiEkonomikiVUkrainiUIPivrichchi2016-Roku

3. Koval, O. P (2016). Sotsialna bezpeka: sutnist ta vymir. Kyiv: NISD. Available at: http://www.niss.gov.ua/public/File/2016_nauk_anal_rozrob/social_bezpek.pdf

4. Metodychni rekomendatsii shchodo rozrakhunku rivnia ekonomichnoi bezpeky Ukrainy. (2013, October). Available at: http://document.ua/pro-zatverdzhennja-metodichnihrekomendacii-shodo-rozrahunku-doc168080.html

5. Schwarz, A. M. (2006) Pension System Reforms. Analyzing the Distributional Impact of Reforms, 2. Available at: http://siteresources.worldbank.org/INTPSIA/Resources/490023-1120845825946/PSIAVOLII printed.pdf

6. Poplyko, V. (2015). Belorusskaia pensionnaia sistema: nemnogo arifmetiki. Pamiatnaia zapiska «Liberalnogo kluba». Available at: http://iberalclub.biz/belorusskaya-pensionnaya-sistema-nemn/lya perevoda

7. Rabotna syla $i$ koefitsienti na ikonomicheska aktivnost - natsionalno nivo; statisticheski raoni. Available at: http://www.nsi.bg/bg/content/4007/rabotna-sila-i-koefitsienti-na-ikonomicheska-aktivnost-natsionalno-nivo-statisticheski

8. Do 2050 roku naselennia Ukrainy skorotytsia do $36 \mathrm{mln}$ osib. Available at: http://dt.ua/UKRAINE/do-2050-roku-naselennyaukrayini-skorotitsya-do-36-mln-osib-124859_html

9. Nasibova, O.V.(2015) Finansove zabezpechennia derzhavnykh pensiinykh zoboviazan $\mathrm{v}$ umovakh transformatsiinoi ekonomiky. Naukovyi visnyk Khersonskoho derzhavnoho universitetu. Seriia Ekonomichni nauky, 12(2), 166-170.

10. Kakvo triabva da znam za doplnitelnoto pensionno osiguriavane. (2009). Sofiia. Available at: http://www.zastrahovatel.com/statia.php?mysid=3364\&t=6\&

$$
\text { Received 18.03.2017 }
$$

